
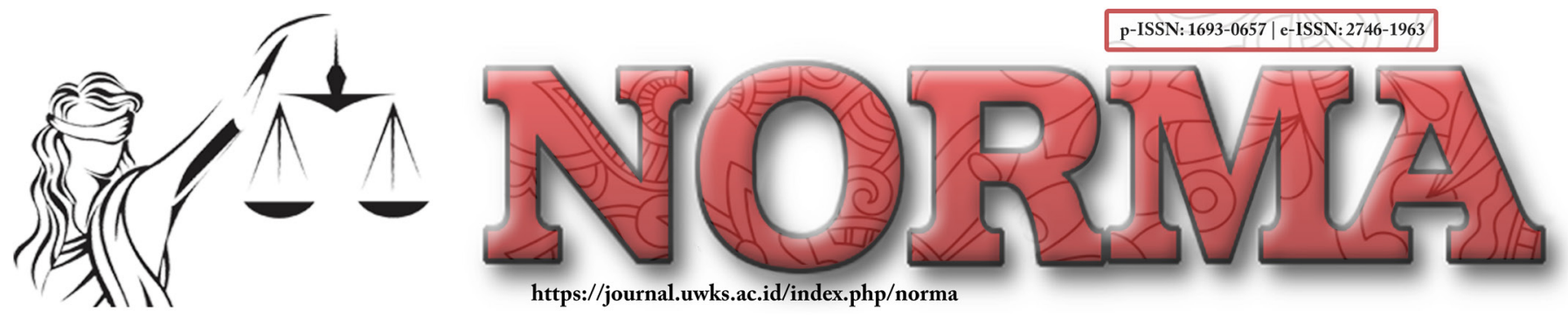

\title{
Limitations of Public Interest Clause in Land Acquisition So That Land Rights Holders Can Retain Their Rights
}

\author{
Rias Frihandini \\ Law Faculty, Universitas Wijaya Kusuma Surabaya \\ e-Mail: riasfrihandini@gmail.com
}

\begin{abstract}
:
This research aims to see and analyze legal protection for land rights holders who lost their land rights due to public interest clause, whether for the benefit of the state or the private sector. Based on the 1945 Constitution, it can be seen that the use of the earth (land), water, and natural resources contained therein by the state is required to be used for the greatest prosperity of the people, and not for certain elites from government agencies who need land. Limitations must be applied to this clause so that the use is not arbitrary because even though the land rights are ownership rights, it can lose since the Government carries it out. The public interest clause is always the way and the Government answer for those who refuse their land to be acquired. Research results are that public interests, which are the needs of many people or broad goals, must pay attention to social, political, psychological, vindication and security aspects based on the National development principle.
\end{abstract}

Keywords: Land; Public Interest; Acquisition.

Article's History:

Received:

February 16, 2021;

Peer-Reviewed:

February 24, 2021;

Accepted:

February 27, 2021;

Published:

March 5, 2021.

DOI:

10.30742/nlj.v18i1.1291

\section{INTRODUCTION}

The Republic of Indonesia aims to promote the general welfare and achieve social justice. Development carried out by the Indonesian people as an effort to achieve a prosperous and prosperous life as determined normatively in Article 33 paragraph (3) of the 1945 Constitution (from now on written the 1945 Constitution) which determines that the earth and water and natural resources which are contained therein shall be controlled by the state and used for the greatest prosperity of the people. From the provisions of Article 33 paragraph (3) of the 1945 Constitution, it can be seen that the use of the earth (land), water, and natural resources contained therein by the state is required to be used for the greatest prosperity of the people, not for the prosperity and welfare of certain groups, especially for certain elites from government agencies who need land. State control rights as stated in Article 33 paragraph (3) of the 1945 Constitution have implications for: first, the state controls the earth, water, and natural resources contained therein; second, the earth, water, and natural resources contained therein (mining materials) used for the greatest prosperity of the people. The state's 
right to control or the right to control the state is a concept based on the people's power organization and for the people. The right to control the state and cover the authority to regulate, administer, and supervise management also contains the obligation to use it for the people's greatest prosperity. ${ }^{1}$

One of the development activities for the public interest through Land Acquisition is Infrastructure Development. One crucial aspect of development is in the physical and social fields. This can be realized by improving existing infrastructure facilities where infrastructure is one of the driving forces for economic growth. Infrastructure, like road facilities, is the modernization of the nation, the provision of which is an essential aspect to increase the smooth productivity of the production sector and last but not least, this road infrastructure can also play a supporting role in creating and increasing access to transportation for people in their activities. Adequate physical infrastructure such as roads and bridges is often associated as a trigger for development developments in various areas. We can quickly assess the differences in the welfare of an area only by looking at the infrastructure gaps that occur within it. In connection with the preceding, for that in the future, the acceleration of infrastructure development is increasingly important to pay more attention to; however, it is inseparable that land rights holders must also pay close attention to their welfare to benefit from the existence of infrastructure such as roads, which can act as a means of opening the isolation of an area from the outside world so that it is expected to have an impact on improving the welfare of the community both in the economic, social and cultural fields.

However, there is a problem in society when land acquisition is not carried out appropriately for development purposes. It does not provide legal certainty and protection for land rights holders; other than that, land rights holders cannot take legal action when their land interests are designated for their interests.

\section{RESEARCH METHOD}

This research is a normative legal research. This research's approach method is a statutory approach. This approach is used because the discussion in this study will refer to the Law and the concept related to the issue.

\section{DISCUSSION}

To create a prosperous and society based on Pancasila and the 1945 Constitution, the Government needs to carry out development. One of the development efforts within the framework of national development that organized by the Government, is development for the Public Interest. Development for the Public Interest requires land that the procurement is carried out by prioritizing the principles contained in the

1 Umar Said Suratman and Noorhudha Muchsin, Hukum Pengadaan Tanah (Malang: Setara Press, 2015) 7 . 
1945 Constitution of the Republic of Indonesia and national land law, including the principles of humanity, justice, benefit, certainty, openness, agreement, participation, welfare, sustainability, and harmony following the values of the nation and state.

Article 6 UUPA states that "All land rights have a social function." This explains that whatever land rights a person has, it cannot be justified that his land will be used or not used solely for his interests, especially if it causes harm to the broader community, in the sense that land functions not only for the holders of land rights but also for the Indonesian nation as a whole, the consequence that the use of rights to a plot of land must also take into account the community's interests. Land use must be adjusted to the circumstances and nature of its rights to be beneficial both for the welfare and happiness of those who have it and for the community and the state. However, this does not mean that a person's interests are constrained by the interests of the community or the state, and between the two interests must be balanced. ${ }^{2}$

Activities involving public interests sacrificing individual interests, then these activities must continue to guarantee the maintenance of fundamental human rights and guarantees, namely the safety of religious beliefs, the safety of soul, the safety of reason, safety of family and descent, and safety of property rights. Activities for the public benefit must be genuinely for the public interest: haqiqiyyah (real) and not wahniah (hypothetical) must not be against the law. They must not sacrifice other public interests equal or more significant. ${ }^{3}$

In the case of land acquisition for public purposes, it always creates excesses that have a large enough impact on the community's stability. Various tensions arise in the community due to disagreements between landowners or land rights holders whose land will be taken for development projects and the authorities tasked with doing this. Besides, problems arise because of unclear rights status.

In practice, legal regulations regarding the release of land rights for government and private purposes do not work following the content and spirit of the provisions so that on the one hand, the impression appears as if the rights and interests of the people who own the land do not receive legal protection. Meanwhile, the Government or parties requiring land also experience difficulties in obtaining land to build their projects. The implementation of land rights release for public interests, come with nuances of the conflict, both from the standpoint of the different legal paradigms between the community and the authorities or the Government, as well as the law enforcement of judges who have a very positivist nuance who ignore other social principles and living law and morals in society.

In Article 19 Paragraph (2) of the UUPA, controlling and using land individually is possible and permitted, this is emphasized in Article 4 Paragraph (1), and Articles

2 Boedi Harsono, Hukum Agraria Indonesia (Sejarah Pembentukan Undang-Undang Pokok Agraria, Isi dan Pelaksanaannya) (Jakarta: Djambatan, 1997) 575.

3 Achmad Sodikin, Politik Hukum Agraria (Jakarta: Konstitusi Press, 2013) 163. 
$21,29,36,42$, and 45 of the UUPA, which contain the requirements for land rights holders. It also shows the principles of individual land tenure and use. However, the individual and private land rights in the UUPA contain an element of togetherness. This togetherness element exists in every right to the land because all land rights directly or indirectly derive from the nation's collective rights. The personal nature of land rights that simultaneously contains elements of togetherness in Article 6 of the UUPA has been confirmed, in which all land rights have a social function. However, one of the problems that are still faced in connection with public interest is determining the balance point between public interest and private interest in development. ${ }^{4}$

Community landowners as individuals or groups who have to give up their rights to their land for public interest or public activities, their socio-economic welfare must be guaranteed by the Government, in other words, landowners after releasing their rights to their land for the public interest, cannot be worse than its original state, at least must be equivalent to the state before the land was released. However, there are often clashes between the Government and the community in practice, owners of land rights who feel the development of this infrastructure has disadvantaged them.

The national land law provides legal protection to land rights holders that the use and control of land by anyone and for anything must be based on land rights provided by the national land law. The control and use of land are legally protected against disturbances from any party, fellow community members, and even the authorities if the disturbance is not based on the applicable legal basis. In other words, if the right holder legally controls the land, if there is a need for land for development, it must be preceded by prior deliberation with the legal owner.

Legal protection in land acquisition for public interest can be broadly interpreted as respect for individual land rights. This is related to the consequences of State recognition of a person's land or a customary law community; the state is obliged to guarantee legal certainty for the land rights so that it is easier for someone to defend their rights against interference from other parties.

For more than half a century, land acquisition for development was only regulated by regulations and/or Presidential Decrees which were inadequate and unattractive. In 2012, Law no. 2 of 2012 concerning Land Acquisition for Development for Public Interest. Aside from the issuance of the Law on Compensation, the UUPA has not yet been revised. The law must reflect the values of living money in society, and the law must be able to answer the demands of society's needs. ${ }^{5}$

In-Law No. 2 of 2012, legal remedies that holders of land rights can take include legal measures in the context of land acquisition and legal remedies in calculating the

4 A. A. Oka Mahendra, Menguak Masalah Hukum Demokrasi Dan Pertanahan (Jakarta: Sinar Harapan, 1996) 256.

5 Rasjidi Lili and Ira Thania Rasjidi, Dasar-dasar Filsafat dan Teori Hukum (Bandung: Citra Aditya Bakti, 2004) 130. 
amount of compensation. Law No. 2 of 2012 is an appreciation of the human rights of citizens as stipulated in the 1945 Constitution. It is listed as follows: Legal Remedies for Rightsholders in the Context of Land Acquisition in Article 23:

1. After the determination of the construction location as referred to in Article 19 Paragraph (6) and Article 22 Paragraph (1), there are still objections, the party entitled to the location determination can file a lawsuit at the local PTUN no later than 30 working days from the issuance of the location determination.

2. PTUN decides whether to accept or reject the lawsuit as referred to in Article 23 Paragraph (1) within 30 working days from the lawsuit's receipt.

3. Parties who object to the PTUN decision as referred to in Article 23 Paragraph (2) within 14 working days can file an appeal to the Supreme Court of the Republic of Indonesia.

4. The Supreme Court is obliged to issue a decision within 30 working days from the time the appeal is received.

Giving boundaries regarding the public interest is not easy, considering that the judgment is very subjective and too abstract to understand. ${ }^{6}$ Besides, the term public interest is a concept that is so general, and there is no more specific and detailed explanation for its operation following the meaning contained in the term.

However, in taking community lands, the affirmation of the public interest will be the basis. The criteria need to be determined so that the land acquisition is following the applicable legal basis. ${ }^{7}$ If the criteria are not formulated or given explicitly, it is feared that this can lead to various interpretations.

The land acquisition mechanism for infrastructure development, which states that it is in the public interest, is regulated by Law no. 2 of 2012. In connection with the implementation of Toll Road construction, it is carried out based on the Regulation of the Head of BPN RI Number 5 of 2012 Jo. Head of BPN Regulation Number 6 of 2015 and Presidential Decree Number 71 of 2012 Jo. Perpres Number 40 of 2014 Jo. Perpres Number 99 of 2014 Jo. Perpres Number 30 of 2015 in conjunction with Presidential Decree Number 148 of 2015 as follows:

Land for development using the arguments of public interest is regulated in Article 10 of the Law. No. 2 of 2012 includes:

a. National defense and security;

b. Public roads, toll roads, tunnels, railways, train stations, and railway operating facilities;

c. Reservoirs, dams, weirs, irrigation, drinking water channels, sewerage and sanitation, and other irrigation structures;

d. Ports, airports, and terminals;

6 Mahendra, Menguak Masalah Hukum Demokrasi Dan Pertanahan 297.

7 Abdurrahman, Pengadaan Tanah Bagi Pelaksanaan Pembangunan Untuk Kepentingan Umum (Bandung: Citra Aditya Bakti, 1994) 36. 
e. Oil, gas, and geothermal infrastructure;

f. Electricity generation, transmission, substation, network, and distribution;

g. Government telecommunications and informatics networks;

h. Waste disposal and processing sites;

i. Government / Regional Government hospitals;

j. Public safety facilities;

k. Government / Regional Government public burial places;

1. Social facilities, public facilities, and public green open spaces;

$\mathrm{m}$. a nature reserve and cultural heritage;

n. Government / regional / village government offices;

o. Arrangement of urban slum settlements and/or land consolidation, as well as housing for low-income people with rental status;

p. Government / regional government educational infrastructure or schools;

q. Government / Regional Government sports infrastructure; and

r. Public markets and public parking lots.

The Government must carry out land acquisition types for the public interest, and the Central Government or Regional Government subsequently owns the land. For agencies requiring land which later belongs to the land, BUMN, except as stated in letters $b$ to $r$, the Government can cooperate with BUMN, BUMD, or private business entities. Then specifically for point, the construction is carried out following statutory regulations. Prohibition regarding the product itself, which does not meet the requirements and standards suitable for use or use or exploitation by consumers;

There are 3 (three) principles that can be drawn so that an activity is genuinely for the public interest:

1. The Government owns these activities: it contains a limitation that individuals or the private sector do not own public interest activities. In other words, the private sector and individuals cannot have the types of public interest activities that require the acquisition of land rights or the state;

2. The Government carries out related development activities: providing a limitation that the Government can only play the process of implementing and managing activity for the public interest;

3. Not seeking profit: limiting the function of activity for the public interest. It is entirely different from the private interest that aims to seek profit, thus qualifying that the public interest activities must not seek profit. ${ }^{8}$

Land acquisition for the implementation of development for the public interest can only be carried out if the development plan's stipulation for the public interest is following and is based on the previously determined Regional Spatial Planning

8 Adrian Sutedi, Implementasi Prinsip Kepentingan Umum dalam Pengadaan Tanah untuk Pembangunan (Jakarta: Sinar Grafika, 2008) 75. 
General Plan. Acquisition of land rights is carried out by taking into account the role of land in human life and respecting legal land rights.

\section{CLOSING}

\section{Conclusion}

Land rights holders' legal protection in land acquisition for public purposes can be broadly interpreted as respect for individual land rights. Regarding the legal protection provided, in general, the 1945 Constitution has protected land rights as regulated in Article 28 letter h paragraph 4. Other arrangements are regulated in several statutory regulations, namely regulated in Article 19 paragraph (2) letter c, Article 23 paragraph (2), Article 38 paragraph (2) UUPA, TAP-MPR RI Number IX Year 2001 points b and j, Law Number 39 the Year 1999 concerning Human Rights. Law No. 2 of 2012 has provided legal protection to landowners. Three principles can be said that a toll road infrastructure work activity is genuinely for the public interest: The Government owns the activity; Related development activities carried out by the Government; Not Seeking profit. Public interest is the need or interest of the public or broad goals by taking into account social, political, psychological, and defense aspects based on the principles of National development, and the principle of the public interest is to prioritize the public interest itself without neglecting personal interests. or group, including land acquisition for the development of public interests, must pay attention to two elements of interest, namely private and public interests. It cannot be just one interest.

\section{Recommendation}

To provide maximum legal protection to land rights holders in land acquisition by the Government in toll road infrastructure work for the public interest, the Government should play an active role and pay more attention to implementation in the field and supervise those who need land. The existence of the Government, in this case, is essential so that in the implementation of land acquisition carried out by agencies that require land, it is not carried out arbitrarily by taking rights to land belonging to the community without providing fair and appropriate compensation. The land acquisition team at the time of carrying out the socialization must explain what is meant by the future steps of infrastructure development activities so that the reasonable objectives of Law no. 2 of 2012 is not polluted by irresponsible parties so that land rights holders feel that the Government considers their rights.

\section{REFERENCES}

Abdurrahman. Pengadaan Tanah Bagi Pelaksanaan Pembangunan Untuk Kepentingan Umum. Bandung: Citra Aditya Bakti, 1994. 
Harsono, Boedi. Hukum Agraria Indonesia (Sejarah Pembentukan Undang-Undang Pokok Agraria, Isi dan Pelaksanaannya). Jakarta: Djambatan, 1997.

Lili, Rasjidi, and Ira Thania Rasjidi. Dasar-dasar Filsafat dan Teori Hukum. Bandung: Citra Aditya Bakti, 2004.

Mahendra, A. A. Oka. Menguak Masalah Hukum Demokrasi Dan Pertanahan. Jakarta: Sinar Harapan, 1996.

Sodikin, Achmad. Politik Hukum Agraria. Jakarta: Konstitusi Press, 2013.

Suratman, Umar Said, and Noorhudha Muchsin. Hukum Pengadaan Tanah. Malang: Setara Press, 2015.

Sutedi, Adrian. Implementasi Prinsip Kepentingan Umum dalam Pengadaan Tanah untuk Pembangunan. Jakarta: Sinar Grafika, 2008. 